\title{
Na vaga do trabalho escravo: o tráfico de trabalhadores engajados de Moçambique para a Ilha Reuniáo no pós-abolição da escravidão colonial francesa
}

Paulo Cesar Gonçalves ${ }^{1 *}$ ${ }^{1}$ Universidade Estadual Paulista Júlio de Mesquita Filho, Assis/SP - Brasil

\section{RESUMO}

$\mathrm{O}$ artigo analisa a relação do engajamento de trabalhadores de Moçambique para a Ilha Reunião com a intensificação da demanda por mão de obra a baixo custo nas regióes tropicais do globo, no período da proibição do tráfico de escravos e da abolição da escravidão, em virtude do crescimento do comércio mundial.

Palavras-chave: Moçambique; Ilha Reunião; tráfico de escravos; trabalho forçado; engajamento sob contrato.

\section{In the place of slave labor: the trafficking of engaged workers from Mozambique to Reunion Island in the post-abolition of French colonial slavery}

\section{ABSTRACT}

The article analyzes the relation of the engagement of Mozambican workers to Reunion Island with the intensification of the demand for low-cost labor in the tropical regions of the globe, during the period of prohibition of the slave trade and the abolition of slavery, due to the growth in world trade.

Keywords: Mozambique; Reunion Island; slave trade; forced labor; indentured labor.

DOI: http://dx.doi.org/10.1590/2237-101X02004203.

Artigo recebido em 15 de novembro de 2017 e aceito para publicação em 29 de outubro de 2018.

* Professor da Universidade Estadual Paulista Júlio de Mesquita Filho / Faculdade de Ciências e Letras / Departamento de História, campus Assis/SP - Brasil. E-mail: pc.goncalves@unesp.br. ORCID: https://orcid. org/0000-0003-3122-0690.

Pesquisa realizada com apoio da Fundação de Amparo à Pesquisa do Estado de São Paulo (FAPESP) na modalidade Auxílio à Pesquisa Regular (Processo no 2018/00615-9) 


\section{En el lugar del trabajo esclavo: el tráfico de trabajadores comprometidos de Mozambique para la Isla Reunión en la post-abolición de la esclavitud francesa}

\section{RESUMEN}

Este artículo analiza la relación del compromiso de trabajadores de Mozambique para la Isla Reunión con la identificación de la demanda de mano de obra a bajo costo en las regiones tropicales del globo, en el periodo de la prohibición del tráfico de esclavos y de la abolición de la esclavitud, en virtud del crecimiento del comercio mundial.

Palabras clave: Mozambique; Isla Reunión; tráfico de esclavos; trabajo forzado; mano de obra sobre contrato.

A partir do corpus documental constituído pela Legislação Régia, Diário da Câmara dos Deputados e relatórios produzidos pelo Estado português sobre a emigração de africanos de Moçambique para a Ilha Reunião, este artigo analisa o engajamento de "colonos livres" no Oceano Índico sob o prisma da extinção do tráfico de escravos, da abolição da escravidão e da relação direta com a intensificação da demanda por mão de obra a baixo custo nas regióes tropicais do globo, em virtude do crescimento do comércio mundial. Ao final, procura investigar como os esforços da metrópole portuguesa para controlar a emigração nativa estavam ligados às primeiras tentativas de mobilização do trabalho forçado, considerado instrumento basilar no fomento da exploração colonial de Moçambique no crepúsculo do Oitocentos.

Alguns estudos já identificaram a importância desse tipo de tráfico no Índico'. No final da década de 1970, Alexandre chamou atenção para o comércio negreiro a partir de Moçambique, menos dependente do mercado brasileiro, como era o de Angola, e, por isso, afetado em menor grau pelo seu encerramento abrupto. Na costa oriental, o trato de escravos fazia-se, desde o século XVIII, em direção às Ilhas Mascarenhas², e prosseguia na segunda metade do Oitocentos, sob a forma de engajamentos de "colonos livres", ao mesmo tempo

${ }^{1}$ CAPELA, José; MEDEIROS, Eduardo. O tráfico de escravos de Moçambique para as ilhas do Índico, 17201902. Maputo: Universidade Eduardo Mondlane, 1987; FUMA, Sudel. Histoire d'un peuple: La Réunion (1848-1900). Saint-Denis: Université de La Réunion/Editions CNH, 1994; NORTHRUP, David. Indentured labor in the age of imperialism, 1834-1922. Nova York: Cambridge University Press, 1995.

2 Sobre o tráfico para as Mascarenhas, ver: TEELOCK, Vijaya; VERNET, Thomas (orgs.). Traites, esclavage et transition vers l'engagisme: perspectives nouvelles sur les Mascareignes et le sud-ouest de l'océan Indien. Réduit: Université de Maurice, 2015. 


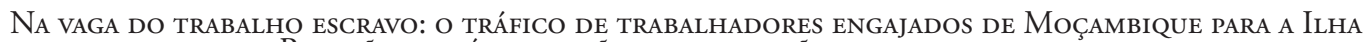

em que crescia a exportação de escravos para Cuba e Sul dos Estados Unidos, praticada por navios norte-americanos que se abasteciam em Moçambique e Zanzibar ${ }^{3}$.

Alexandre deixou pistas a serem seguidas ao apontar que as duas questóes - o engajamento de colonos e o tráfico - ocuparam parte da correspondência entre Moçambique e Lisboa, nas décadas de 1850 e 18604 . Lembrou, ainda, que, mesmo com a derrota dos estados do Sul na Guerra da Secessão dos Estados Unidos (1867) e a abolição da escravidão em Cuba (1886), subsistiram formas de exportação de mão de obra, toleradas internacionalmente, que se aproximavam do comércio de escravos pela situação concreta criada aos trabalhadores e pela coação sobre eles exercida, impedindo o retorno ao local de origem. Em síntese, o historiador identificou a importância de se estudar a "emigração de colonos livres" africanos, indianos, chineses, portugueses para vários pontos do mundo, em circuitos que mereceriam abordagem global, indispensável à compreensão exata do fenômeno da extinção do tráfico, que eles vieram a substituir. Estudos mais recentes também assinalaram a simultaneidade e a continuidade entre o tráfico de escravos e o engajamento de trabalhadores no Índico, assim como sua articulação em nível global. ${ }^{5}$

Para Blackburn, a imigração sob contrato de trabalho (indentured labor) foi a solução encontrada para substituir a escravidão nas plantations, após a abolição nas colônias britânicas e francesas do Caribe, demonstrando que a exigência econômica pelo trabalho servil não desapareceu. Mais do que isso, a utilização de trabalhadores sob contrato de servidão evidenciou que a própria emancipação não foi apenas resultado da demanda do capital por um novo tipo de mão de obra, mas também da sua incapacidade para manter a forma existente de escravidão ${ }^{6}$. Na mesma trilha, mas focando as áreas do Índico, Chaillou-Atrous assinala que a progressiva abolição do comércio de escravos e da escravidão nas colônias europeias esteve na origem de novas migraçóes de trabalhadores pelo mundo. Força de trabalho exógena sob contrato, arregimentada por uma política de Estado apoiada no argumento da incapacidade dos ex-escravos de trabalhar após a liberdade. Javaneses, tonquineses, africanos, mas, especialmente, chineses e indianos deixaram seu solo nativo para trabalhar, em troca de parcos salários, nas antigas colônias da América, do Índico e nos territórios recém-conquistados pelos europeus na África, Ásia e Pacífico?.

\footnotetext{
${ }^{3}$ ALEXANDRE, Valentim. Origens do colonialismo português moderno. Lisboa: Sá da Costa, 1979, p. 50-51.

${ }^{4}$ ALEXANDRE, Valentim. Origens do colonialismo... op. cit., p. 51.

${ }^{5}$ CAPELA, José. O tráfico de escravos nos portos de Moçambique. Porto: Afrontamento, 2002; ALLEN, Richard B. European slave trading in the Indian Ocean, 1500-1850. Athens: Ohio University Press, 2014; ALLEN, Richard B. Slaves, convicts, abolitionism and the global origins of the post-emancipation indentured labor system. Slavery \& Abolition, v. 35, n. 2, 2014; STANZIANI, Alessandro. Bondage: labor and rights in Eurasia from the Sixteenth to the early Twentieth centuries. Nova York; Londres: Berghahn Books, 2014.

${ }^{6}$ BLACKBURN, Robin. A queda do escravismo colonial: 1776-1848. Rio de Janeiro: Record, 2002, p. 576.

${ }^{7}$ CHAILLOU-ATROUS, Virginie. La reprise de l'immigration africaine à La Réunion à la fin du XIXème siècle: de la traite déguisée à l'engagement de travail libre. French Colonial History, v. 16, 2016, p. 28.
} 
Na Vaga do trabalho escravo: o tráfico de trabalhadores engajados de MoçambiQue para a IlHa

Apesar de o trabalho sob contrato expandir-se muito após a abolição do tráfico e da escravidáo, como afirma Blackburn, cabe lembrar que essa forma de trabalho coexistiu com a escravidão e o infame comércio no Atlântico e, sobretudo, no Índico. De acordo com Allen, o sistema de engajamento tomou forma um quarto de século antes do que acreditava a historiografia. As ilhas Mascarenhas, em particular, as Maurício, desempenharam papel importante no surgimento de sistemas de trabalho sob contrato durante a década de 1830, mas os registros arquivísticos revelam tentativas britânicas de usar mão de obra asiática contratada com antecedência de duas décadas, quando, em 1806, duzentos trabalhadores agrícolas chineses foram recrutados como mão de obra para a recém-adquirida colônia britânica de Trinidad, no Caribe ${ }^{8}$.

Esse tipo de engajamento esteve presente em diversas áreas ao redor do globo, tanto em termos da demanda - Índias Ocidentais, Cuba, Peru, Guianas, Havaí, Ilhas Maurício, Ilha Reuniāo, Transvaal - quanto nas regiōes de origem dos trabalhadores - Ásia, África, ilhas do Pacífico Sul, Ilha da Madeira e Açores. Os números são bastante significativos e indicam a importância desse tipo de tráfico. Segundo Northrup, entre 1831 e 1920, pouco mais de dois milhôes de pessoas, sobretudo chineses e indianos deslocaram-se sob a égide da imigração sob contrato. Desses, 927 mil chegaram às Américas, sendo o Caribe britânico seu principal receptor, com quase $530 \mathrm{mil}$, mas outras áreas também receberam contingentes expressivos: Caribe francês (100 mil), Havaí (115 mil), Ilhas Maurício (452 mil), Ilha Reunião (111 mil), Natal (152 mil) e Transvaal (63 mil). O período áureo ocorreu entre as décadas de 1850 e 1870, com médias anuais de 44 mil, 33 mil e 27 mil para cada decênio, respectivamente?

Ao final do século XVIII, a despeito da prosperidade das colônias do Novo Mundo, a escravidáo e o tráfico de escravos começaram a ser combatidos na Europa, sobretudo na Grã-Bretanha. A campanha contra o tráfico negreiro foi referendada pela lei de março de 1807 , que o proibiu a partir de $1^{\circ}$ de janeiro do ano seguinte. Encabeçando a repressáo ao tráfico, os britânicos direcionaram suas forças aos impérios ibéricos através do patrulhamento do oceano, de tratados de busca e apreensão, além de intervençóes em solo africano para libertar escravos antes do embarque.

Após o fim das guerras napoleônicas, as potências europeias, à exceção de Portugal e Espanha, concordaram em abolir o comércio de escravos. Em 1815, Grã-Bretanha e Portugal assinaram um tratado que o proibia acima da linha do equador, mas a nação ibérica prosseguiu traficando cativos para sua colônia americana. Com a independência do Brasil, a pressão britânica voltou-se para a ex-colônia, que resistiu até 1850. Com relação à Espanha, após a perda de grande parte do império americano, a Coroa voltou-se para economia açucareira em Cuba, cuja demanda por escravos impôs forte resistência contra o fim do tráfico

\footnotetext{
${ }^{8}$ ALLEN, Richard B. Slaves, convicts, abolitionism... op. cit., p. 332.

${ }^{9}$ NORTHRUP, David. Indentured labor... op. cit., p. 159-161.
} 


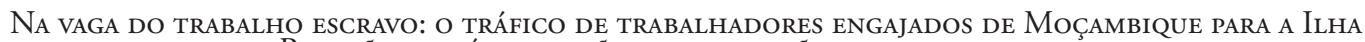

até a década de 1860. Os Estados Unidos, mesmo com a promulgação de várias leis que proibiam o tráfico, continuaram a riscar o Atlântico com seus navios negreiros até princípios da mesma década ${ }^{10}$.

Foram exatamente as áreas onde o sistema baseado no trabalho escravo persistiu, que, ancoradas na crescente demanda de produtos das plantations, apresentaram vitalidade econômica garantida pela participação no comércio mundial diante da divisão internacional do trabalho como resposta à nova fase do imperialismo em que o capital ocidental intensificou os investimentos ultramarinos. Com terras e capitais disponíveis, o braço escravo tornava-se ainda mais imprescindível, fato evidenciado pela chegada ao Brasil e Cuba de mais de 2,7 milhôes de africanos cativos entre 1801 e 1867. Como assinala Blackburn, a escravidão no Novo Mundo não era mais colonial, mas sim colonizadora ${ }^{11}$. Por outro lado, o fluxo considerável de trabalhadores sob contrato para as Índias Ocidentais britânicas e francesas, Peru, Cuba, Havaí e territórios coloniais nos Oceanos Índico e Pacífico refletiu a busca por mão de obra barata mediante condiçóes particulares, em que a ausência do escravo não podia ser compensada pela atração de trabalhadores livres.

No período em que a Grã-Bretanha pôs fim à escravidão nas colônias (1833), reflexo do movimento abolicionista iniciado no final do século XVIII, e a Marinha Real intensificava o patrulhamento do Atlântico em busca de navios negreiros, o trabalho sob contrato foi utilizado para empregar nas colônias os escravos resgatados do tráfico. O recrutamento de africanos unia estrategicamente os esforços navais e diplomáticos para reprimir o tráfico negreiro à busca por novas fontes de mão de obra empreendida pelos governos coloniais e pelo Colonial Office. Quando, em 1841, foi sancionado o esquema de recrutamento de africanos estabelecido nas colônias, o Foreign Office voltou-se para o tráfico de escravos destinados ao Brasil e Cuba. No caso do ramo brasileiro, o total desviado para as colônias britânicas no Caribe pode ter chegado a 10 mil africanos ${ }^{12}$.

No Índico, os escravos dos navios apresados pela marinha britânica tinham destino semelhante. Capela observou que náo se restituiu a liberdade a esses resgatados: nos anos de 1840, foram encaminhados ao Cabo da Boa Esperança, onde, acorrentados e com alimentação insuficiente, trabalhavam em serviços públicos; na década de 1860, os escravos "libertados" pela armada britânica das embarcações árabes responsáveis pelo tráfico ilegal

\footnotetext{
${ }^{10}$ As leis de 1794, 1800, 1808, 1819 e 1820 pouco serviram para desestimular o comércio transatlântico de escravos ao longo da costa leste. GRADEN, Dale. O envolvimento dos Estados Unidos no comércio transatlântico de escravos para o Brasil (1840-1858). Afro-Ásia. Salvador, v. 35, 2007, p. 34.

${ }^{11}$ BLACKBURN, Robin. A queda do escravismo colonial. op. cit., p. 582. Esse período de intensificação da exploração do trabalho escravo em resposta ao crescimento do comércio internacional é denominado de "segunda escravidão". Cf. TOMICH, Dale. Pelo prisma da escravidão: trabalho, capital e economia mundial. Sáo Paulo: Edusp, 2012.

${ }^{12}$ MAMIGONIAN, Beatriz G. Em nome da liberdade: abolição do tráfico de escravos, o direito e o ramo brasileiro do recrutamento de africanos (Brasil - Caribe britânico, 1830-1850). Revista Mundos do Trabalho. Campinas/SP, v. 3, n. 6, 2011, p. 82.
} 
Na Vaga do trabalho escravo: o tráfico de trabalhadores engajados de MoçambiQue para a IlHa

eram geralmente levados para as Seychelles, onde serviam como aprendizes nas plantaçóes, sob as ordens dos proprietários. ${ }^{13}$

Nas colônias francesas, o contrato de engajamento ou serviço contratado foi desenvolvido no século XVII. Inicialmente, destinava-se aos colonos brancos, cujas despesas de transporte foram pagas pelos empregadores ou seus intermediários em troca do compromisso de trabalho por vários anos. Os engajados estavam sujeitos a penalidades criminais e poderiam ser transferidos juntamente com seu contrato para outros senhores. Segundo Stanziani, para além do comércio envolvido, os contratos de engajamento devem ser qualificados de acordo com o destino - Antilhas Francesas, Canadá ou Oceano Índico - e o período histórico. Nos séculos XVII e XVIII, os contratos diziam respeito aos brancos encaminhados às Índias Ocidentais francesas, Canadá e ilhas do Índico, e persistiram, estabelecendo sançôes penais, até a década de 1830. Para indianos, africanos e chineses, os engajamentos e as correspondentes formas de servidão continuaram a ser praticados até o início do século XX. E o mais importante, o contrato de servidáo em troca do pagamento antecipado das despesas de transporte pelo senhor ou intermediário, considerado pelos historiadores como uma forma de trabalho forçado, não entrou nessa categoria até meados do século XIX ${ }^{14}$.

Stanziani também ressalta as diferenças do tráfico de escravos e da escravidão no Índico em relação ao Atlântico. A regiáo Índica formou um tipo de economia global que precedeu a Atlântica. O tráfico começou entre os indianos, árabes e africanos já no século VII, muito antes de seu homólogo transatlântico e continuou bem além dele - até o século XX. O comércio de escravos no Índico também era multidirecional e, ao longo do tempo, seus principais destinos mudaram. As múltiplas formas de escravidão apresentavam estatutos diversos: escravos de palácios, escravos soldados, mulheres e crianças escravas e trabalhadores escravos na agricultura e na manufatura. Para o historiador, o significado da escravidão no Oceano Índico só se torna inteligível quando analisado fora das categorias de escravidão antiga ou norte-americana. Muitas vezes, implicava configuraçóes mútuas de dependência em que um indivíduo, grupo ou casta de status inferior estava obrigado a outro considerado superior. Consequentemente, as formas de obrigação de status, escravidão e escravidão temporária - a mais comum por dívida - coexistiram com formas de escravidão semelhantes às da América ${ }^{15}$.

As Ilhas Mascarenhas eram exceção na medida em que desenvolveram uma economia de plantação e formas de escravidão similares à Atlântica. Estima-se que 160 mil escravos foram importados antes de 1810, vindos de Madagascar (70\%), Moçambique e África Oriental (19\%). Um comércio tão significativo que, de acordo com Allen, influenciou as políticas imperiais britânicas de repressão ao tráfico e a abolição da escravidão no Índico e o subsequente

\footnotetext{
${ }^{13}$ CAPELA, José. O tráfico de escravos... op. cit., p. 270-271.

${ }^{14}$ STANZIANI, Alessandro. Beyond colonialism: servants, wage earners and indentured migrants in rural France and on Reunion Island (c. 1750-1900). Labor History, v. 54, n. 1, 2013, p. 71-72.

${ }^{15}$ STANZIANI, Alessandro. Beyond colonialism. op. cit., p. 72.
} 


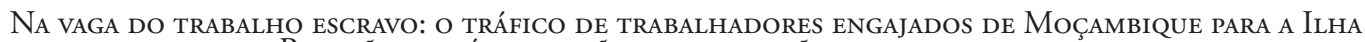
REUNIẪO NO PÓS-ABOLIÇÃ̃ DA ESCRAVIDÃO COLONIAL FRANCESA

Paulo Cesar Gonçalves

recurso ao trabalho sob contrato ${ }^{16}$. Na Ilha Reuniáo, ao lado do uso de escravos, engajados foram empregados no século XVIII e até mesmo no século XIX. Essa imigração esteve parcialmente ligada à necessidade de artesãos indianos, mas, sobretudo, à demanda por trabalhadores adicionais no momento em que, sob pressão inglesa, o preço dos escravos aumentava constantemente e cresciam os rumores da abolição da escravidão nas colônias francesas ${ }^{17}$.

Desde o início do século XVIII, a França desempenhou papel central na organização do tráfico de escravos na África Oriental. Após as guerras napoleônicas, mesmo com a reintrodução oficial da escravidão em $1802^{18}$, determinadas importaçôes de escravos assumiram a forma de contratos de engajamento. Considerando os censos oficiais e as importaçóes disfarçadas, de 48.900 a 66.400 escravos chegaram à Ilha Reuniáo, entre 1811 e $1848^{19}$. Cerca de 300 mil escravos foram enviados para as Ilhas Mascarenhas entre o século XVIII e a primeira metade do XIX. Ao contrário do século XVIII, dessa vez, a África Oriental e Moçambique configuraram-se na principal fonte de suprimento (60\%), com o restante proveniente de Madagascar (31\%) e dos países do sul da Ásia $(9 \%)^{20}$. Mesmo após a abolição da escravidão, essas redes permaneceram ativas engajando trabalhadores através das mesmas práticas do tráfico negreiro.

Nesses circuitos, enquadraram-se a exportação de "colonos livres" de Moçambique para Reunião - objeto deste artigo - e o transporte de africanos, a partir dos portos de Angola para São Tomé, ambos já iniciados na primeira metade do século XIX. Vale destacar ainda o grande fluxo de chineses, denominados "coolies", que deixaram seu território através dos portos de Macau, enclave português no Império chinês, e de Hong Kong, território britânico na China, para trabalhar nas áreas coloniais tropicais, e de indianos, o principal contingente, com cerca de 1,3 milhóes de engajados ${ }^{21}$.

Céline Flory estudou o "resgate" de cativos africanos antes e depois da segunda abolição da escravidão no império francês ${ }^{22}$. Sistema legalmente estruturado em torno da alforria sob

\footnotetext{
${ }^{16}$ ALLEN, Richard B. Slaves, convicts, abolitionism... op. cit., p. 337.

${ }^{17}$ STANZIANI, Alessandro. Beyond colonialism. op. cit., p. 72.

${ }^{18}$ A primeira abolição da escravidão ocorreu em 4 de fevereiro de 1794 , na fase jacobina da Revolução Francesa. Na prática, com a necessidade de continuar a produção nas grandes plantaçóes, a emancipação manifestou-se pela instituição de regimes híbridos de trabalho combinando formas de remuneração com restriçôes à liberdade. A escravidão colonial foi restabelecida em 1802 por Napoleão. Sobre o tema, ver: SAES, Laurent A. M. A primeira aboliçấo francesa da escravidão (4 de fevereiro de 1794) e o problema dos regimes de trabalho. Saeculum - Revista de História. João Pessoa, v. 29, 2013.

${ }^{19}$ STANZIANI, Alessandro. Beyond colonialism. op. cit., p. 73. Segundo Capela e Medeiros, entre 1800 e 1854, o tráfico para as ilhas do Índico chegou a 255 mil escravos. CAPELA, José; MEDEIROS, Eduardo. $O$ tráfico de escravos... op. cit., p. 41.

${ }^{20}$ ALLEN, Richard. The Mascarene slave-trade and labour migration in the Indian Ocean during the Eighteenth and Nineteenth Centuries. In: CAMPBELL, Gwyn (org.). The structure of slavery in Indian Ocean, Africa and Asia. London: Frank Cass, 2004, p. 37-38.

${ }^{21}$ NORTHRUP, David. Indentured labor... op. cit., p. 156-157.

${ }^{22}$ FLORY, Céline. De l'esclavage à la liberté forcée. Histoire des travailleurs africains engagés dans la Caraïbe française du XIXe siècle. Paris: Société des Africanistes, 2015. Ver ainda: FLORY, Céline. Alforriar sem liber-
} 


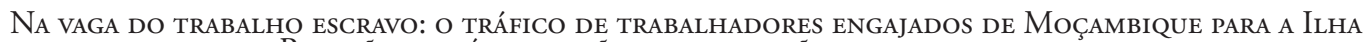

a condição de emigrar e trabalhar por um tempo determinado para pagar o preço da libertação. O engajamento, que funcionava sem o consentimento formal do trabalhador africano em relação aos termos do contrato, tinha por objetivo suprir as plantations da Guiana Francesa e das ilhas do Caribe francês, prática também utilizada na Reunião e em outras colônias do Índico. O sistema de "resgate" beneficiou-se das estruturas estabelecidas pelo tráfico de escravos na África e era sancionado pelo governo francês, mesmo após a aboliçãa ${ }^{23}$.

O fim do tráfico (15 de abril de 1818) e a abolição da escravidão (27 de abril de 1848) desorganizaram sucessivamente a produção nas colônias francesas, e os fazendeiros passaram a reivindicar força de trabalho junto à metrópole. A segunda metade da década de 1820 registrou a rápida expansão da indústria açucareira das ilhas Maurício e Reunião, em contraste com o declínio do comércio de escravos e as experiências fracassadas de reprodução dessa populaçáo. A crescente demanda por mão de obra implicou o recrutamento de 3.100 trabalhadores indianos livres para Reunião e 1.500 trabalhadores chineses e indianos para Maurício. No entanto, as tentativas de empregar asiáticos engajados falharam em face da resistência às péssimas condiçóes de vida e de trabalho ${ }^{24}$. Em vista disso, os fazendeiros da Reunião voltaram-se aos africanos: o transporte era mais barato, os contratos menos onerosos e mais longos, a estrutura do tráfico poderia ser mantida, e a experiência com os escravos parecia indicar menor possibilidade de sublevação ${ }^{25}$.

Na Reunião, entre 1851 e 1854, chegaram, em média, quatro mil africanos engajados por ano; em 1858, cerca de 10 mil, e 5 mil no ano seguinte. O recrutamento em Moçambique, Madagascar e na extensão do litoral africano baseava-se em redes antigas, implantadas no século XVIII, e empregou os mesmos métodos violentos do período escravista, com apoio dos chefes tribais locais. A anexação de Mayotte, em 1841, abriu oportunidades de recrutamento nas Comores, Madagascar e na África Oriental. Em 1853, a França construiu novos centros de trânsito no Gabão e no Senegal. Entre 1856-1866, uma segunda fase teve lugar em Mayotte, por onde passaram cerca de oito mil trabalhadores contratados, quase todos de Moçambique, destinados à Reunião ${ }^{26}$.

A concomitância entre abolição e "resgate", portanto, não foi fortuita. No início, a solução encontrada foi instrumentalizar a alforria para obtenção de mão de obra. Entre 1819 e

tar: a prática do "resgate" de cativos africanos no espaço colonial francês no século XIX. Revista Mundos do Trabalho. Campinas/SP, v. 3, n. 6, 2011.

${ }^{23}$ FLORY, Céline. Alforriar sem libertar. op. cit., p. 93.

${ }^{24}$ ALLEN, Richard B. Slaves, convicts, abolitionism... op. cit., p. 331-332.

${ }^{25}$ Observaçôes do governador-geral de Moçambique, João da Costa Xavier, ao ministro do Ultramar em 1849. Apud CAPELA, José. O tráfico de escravos... op. cit., p. 54. Muitos dos indianos engajados já pertenciam a castas ou já haviam experimentado relaçóes de dependência servil que, a seus olhos, se assemelhavam aos contratos de engajamento. STANZIANI, Alessandro. Beyond colonialism. op. cit., p. 73. Essa experiência, no entanto, não pertencia ao cotidiano das populaçóes africanas da África Oriental, acostumadas apenas às relaçóes escravistas.

${ }^{26}$ STANZIANI, Alessandro. Travail, droits et immigration. Une comparaison entre l'île Maurice et l'île de La Réunion, années 1840-1880. Le Mouvement Social, v. 4, n. 241, 2012, p. 54. 


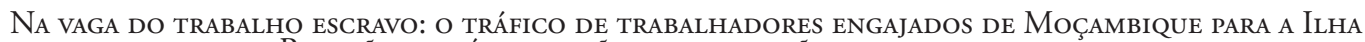

1848, o processo de alforria no resgate de cativos apoiou-se no sistema dos "contratos temporários". Compunha-se de três etapas: a compra do indivíduo, sua alforria e a contratação para trabalhar durante anos para quem o comprou/alforriou, ou por cessão a quem adquiriu seu contrato de trabalho. Ou seja, mesmo que o indivíduo fosse emancipado logo após sua compra, somente se tornaria livre por estatuto e condição apenas ao final do contrato de trabalho. Após a proibição dos contratos temporários e a abolição da escravidão pelo mesmo decreto em 1848, estabeleceu-se, entre 1856 e 1862, o "sistema transoceânico de contratação de africanos" com uma especificidade: as compras de futuros "resgatados" só poderiam ser realizadas nas zonas não francesas, pois o solo francês alforriaria todo escravo que ali chegasse. O negócio era, entâo, efetuado em territórios estrangeiros com oferta abundante de escravos, ou seja, nos mesmos mercados que abasteciam os negreiros ${ }^{27}$.

Para os objetivos deste artigo, não cabe aqui a discussão aprofundada das práticas relacionadas aos "contratos temporários", mas a análise do segundo momento, quando se instituiu o "sistema de engajamento de africanos", considerado por Chaillou-Atrous como prolongamento do tráfico de escravos sob disfarce de um habilidoso aparato legal, que, segundo Alpers, já era praticado pelos franceses no Senegal, desde 1839-184028. O "resgate" baseava-se na compra do cativo e no contrato para trabalhar durante anos, o que, na prática, significava a dupla sujeição do resgatado: a monetária e o trabalho forçado. Uma vez deixada a condição de escravo, os indivíduos comprados estavam endividados em razão do preço da libertação, devendo, então, reembolsar o comprador. Não possuindo outros meios além da força de trabalho, restava o contrato de engajamento para quitação da dívida. Seus direitos eram limitados pelo preço a pagar pela liberdade futura. Dessa forma, esses homens comprados apareciam como imigrantes contratados, à semelhança de indianos e chineses, que também chegavam como engajados naquele momento ${ }^{29}$.

Os números do "sistema transoceânico de contratação de africanos" são bastante significativos. No período de 1856 a 1861, 17.289 resgatados foram contratados por proprietários de terras para o cultivo de produtos coloniais na Guiana e nas Antilhas francesas, enquanto que, na Ilha Reunião, estima-se em $23.368^{30}$. O exemplo francês aqui evocado através do estudo de Flory vincula-se à colônia portuguesa de Moçambique, na linha de continuidade entre o tráfico transoceânico de escravos e o de supostos "colonos livres", pois, como afirmou a historiadora, esse sistema também foi utilizado no recrutamento para Reunião.

\footnotetext{
${ }^{27}$ FLORY, Céline. Alforriar sem libertar. op. cit., p. 95-97.

${ }^{28}$ CHAILLOU-ATROUS, Virginie. La reprise de l'immigration africaine à La Réunion à la fin du XIXème siècle, op. cit., p. 28. ALPERS, Edward A. "le caractère d'une traite d'esclaves déguisée (the nature of a disguised slave trade)"? Labor recruitment for La Réunion at Portuguese Mozambique, 1887-1889, Ufahamu: A Journal of African Studies, v. 40, n. 1, 2018, p. 5.

${ }^{29}$ FLORY, Céline. Alforriar sem libertar. op. cit., p. 100.

${ }^{30}$ FLORY, Céline. Alforriar sem libertar. op. cit., p. 101.
} 
Na Vaga do trabalho escravo: o tráfico de trabalhadores engajados de MoçambiQue para a IlHa

No início da década de 1850, o tráfico de escravos passou a ser, nominalmente, recrutamento de trabalhadores "livres" engajados e as incursôes de embarcaçôes francesas não cessaram. Em 1851, por exemplo, dois navios estiveram nas Ilhas de Cabo Delgado para comprar escravos e torná-los livres depois de servirem ao governo da Reunião pelo prazo de 5 anos $^{31}$. Em resposta, a legislação régia portuguesa tratou explicitamente desse comércio em 27 de fevereiro de 1855, quando, através de decreto, denegou o pedido de franceses proprietários de plantaçóes na Reuniáo para recrutarem trabalhadores em Inhambane. No mesmo despacho, ratificou-se ao governador de Moçambique a proibição do engajamento, bem como a saída dos nativos por portos da província ${ }^{32}$. Um ano depois, a Portaria de 30 de julho, nas primeiras linhas, deixava claro do que se tratava - "a saída de negros, debaixo da denominação de colonos, d'aquella Provincia para a Ilha da Reunião"33 - e confirmava a normativa anterior, motivada pelo pedido do governador que julgava conveniente a saída de nativos.

A leitura atenta da resposta negativa do Conselho Ultramarino ao governador permite identificar as estratégias do recrutamento à semelhança do que apontou Flory, nomeadamente os relatos da vinda de vapores das ilhas Maurício e Reuniáo para recrutar e transportar "colonos" através de contratos ditos "comprovadamente legais".

O pretexto de serem ajustados como trabalhadores livres, para irem servir temporariamente em outros países, na realidade, concorria para a continuação do tráfico da escravatura, transportando dos sertóes aos portos os escravos para os especuladores venderem os seus serviços aos exportadores, iludindo-se assim as disposições dos decretos de 10 de dezembro de 1836 e 14 de dezembro de 1854 ;

Processos instaurados perante os tribunais da Ilha da Reuniáo indicavam que os negros procedentes de Madagascar e do continente africano, transportados como colonos para aquela ilha, foram, para esse fim, comprados aos mercadores indígenas pelos árabes e outros especuladores, os quais os venderam aos comissários da Ilha da Reunião, fazendo-se nesta transferência certos papeis chamados contrato de ajuste de serviços por tempo limitado com os denominados colonos;

Que por notícias dadas pelas folhas públicas e por cartas particulares consta que do Ibo saíra um navio carregado com os denominados colonos, que, em número de 324, foram desembarcados na Ilha Maurício; e que ao porto de Moçambique, tendo chegado cinco navios para o ajuste dos ditos denominados colonos, um deles já havia saído carregado, pagando os especuladores da Ilha de Reuniáo pelo preço de 18 a 20 pesos duros por cada um dos mesmos colonos; (...)

\footnotetext{
${ }^{31}$ CAPELA, José; MEDEIROS, Eduardo. O tráfico de escravos... op. cit., p. 40.

${ }^{32}$ Legislação Régia, Repartição da Marinha, Portaria no 1.394 de 27 de fevereiro de 1855, p. 19-20.

${ }^{33}$ Legislação Régia, Repartição da Marinha, Portaria de 30 de julho de 1856, p. 279.
} 
Na Vaga do trabalho escravo: o tráfico de trabalhadores engajados de MoçambiQue para a IlHa

Que o Governador Geral mande interromper a execução das ordens que tenha expedido, autorizando a saída de negros da província, devendo declarar por essa mesma ocasião nulos e como se nunca tivessem existido quaisquer contratos pendentes para o embarque dos denominados colonos; contratos que são considerados nulos, porque o Governador estava impedido de os permitir, o que os especuladores estrangeiros sabiam perfeitamente, como demonstra o Ofício no 192 , em que dá parte de não ter permitido ao capitão do barco a vapor francês - Mascarenhas - o ajuste de colonos, mostrando-lhe que negociações d'essa ordem se achavam prohibidas, para a prova do que lhe dava conhecimento da Portaria de 27 de fevereiro de 1855 ;

Que o Governador Geral remeta sem perda de tempo uma relação de todos os indivíduos contratados e exportados como colonos, designando quais foram ajustados entre os habitantes livres, os que foram tirados da classe dos escravos declarados libertos ad hoc, e dentre os libertos já assim reconhecidos anteriormente aos contratos; declarando outrossim qual o preço por que cada um foi contratado nas três diferentes hipóteses, e qual a soma por que cada um dos senhores de escravos foi indenizado do serviço dos escravos que libertou para o fim de serem exportados como colonos livres. ${ }^{34}$

Apesar da proibição, navios franceses continuaram aportando em Moçambique, segundo informaçóes remetidas pelo governador do distrito de Cabo Delgado ao Ministério dos Negócios da Marinha e Ultramar, no final de 1857.

As embarcações vindas da Ilha da Reunião traziam a documentação de acordo com a legislação, um delegado da administração a bordo, instruçóes escritas sobre o modo de proceder ao contrato, embarque e condução dos colonos que os navios vêm autorizados pelo governo francês a contratar e a conduzir para aquela ilha, em conformidade com a Lei do Império francês de 1852. Tais navios, nas referidas circunstâncias de legalidade, podem aportar em algum porto para procederem ao referido engajamento e embarque de colonos. Essas embarcaçóes, no entanto, trazem alguns objetos que o Decreto de 10 de dezembro de 1836 menciona como indícios do tráfico da escravatura, o que permitiria a sua detenção, causando embaraços diplomáticos. ${ }^{35}$

Amparados pela legislação francesa, mas, em desacordo com as leis portuguesas. Para evitar problemas com a França, a Portaria definiu os procedimentos a serem observados em relação à chegada de navios franceses com o objetivo de engajar e transportar "colonos".

\footnotetext{
${ }^{34}$ Legislação Régia, Portaria de 30 de julho de 1856, op. cit., p. 279-280.

${ }^{35}$ Legislação Régia, Ministério dos Negócios da Marinha e Ultramar. Seção do Ultramar, Portaria de 20 de novembro de 1857 , p. 5.
} 
Na Vaga do trabalho escravo: o tráfico de trabalhadores engajados de MoçambiQue para a IlHa

Após o escrupuloso exame de todos os papeis do navio - ato de propriedade do navio, carta de francisation, rol da equipagem, manifestos, e as respectivas instruçóes do delegado dadas pela administração da Reunião - deve-se intimar os responsáveis da proibição de realizar embarques ou engajamentos de colonos, exigindo do capitão do navio uma declaração, segundo o modelo junto, e comunicar oficialmente ao delegado de que não será consentido que se façam os engajamentos a que o navio veio destinado, exigindo que lhe enviem documento de que receberam e estão cientes dessa intimação. Os documentos deverão ser enviados à Secretaria Geral. ${ }^{36}$

Esperava-se, assim, que os navios supostamente autorizados não continuassem a frequentar os portos da província para engajar "colonos livres".

Não só pelas comunicações que a este respeito o Governador da metropole deve ter feito ao Governo de Sua Magestade o Imperador dos Franceses, mas tambem pelas feitas ultimamente por este Governo ao Governo da Ilha da Reunião e ao Consul portuguez ali residente. É por isso que se deve despertar o seu cuidado para que não possa ser illudido sobre a legalidade dos documentos que lhe forem apresentados; e, portanto, procurará todos os meios de bem os avaliar ${ }^{37}$.

Em 27 de novembro de 1857, através de denúncia do cônsul inglês, o governo de Moçambique apreendeu a embarcação francesa Charles et Georges que transportava engajados africanos para a Ilha Reunião, sob suspeita de praticar tráfico de escravos. O grave incidente diplomático entre os dois países repercutiu, inclusive, na Câmara dos Deputados ${ }^{38}$. Conforme o processo citado pelo deputado Barros de Sá, "tudo indicava que se tratava de tráfico de escravos", pois foram encontrados "cento e dez negros a bordo, alguns dos quaes estavam presos e amarrados, 'ainda que por sua livre vontade', como dizia o capitão Rouxel”, sendo que "alguns deles tinham sido furtados a proprietários de Moçambique, outros tinham fugido aos seus senhores e depois foram vendidos ao capitão" 39 .

Os relatos de alguns dos africanos encontrados na Charles et Georges à comissão criada em Moçambique para investigar o caso ilustram a estratégia empregada no engajamento de trabalhadores para Reunião: comprar os indivíduos escravizados e transportá-los como livres sob contrato de trabalho.

\footnotetext{
${ }^{36}$ Legislação Régia, Portaria de 20 de novembro de 1857, op. cit., p. 6.

${ }^{37}$ Idem.

${ }^{38}$ A embarcação foi apreendida, levada até Lisboa, e seu capitáo, julgado e condenado a pagar uma multa e a dois anos de trabalho forçado. O governo francês não aceitou a decisão, e o episódio transformou-se em incidente diplomático. O governo português acabou cedendo, e, em 1859, o capitão ganhou a liberdade, e o navio foi devolvido. ALEXANDRE, Valentim; DIAS, Jill (orgs.). O Império africano (1825-1890), v. X. SERRÃO, Joel; MARQUES, A. H. de Oliveira (dir.). Nova História da expansão portuguesa. Lisboa: Editorial Estampa, 1998, p. 596.

${ }^{39}$ Monarquia Constitucional. Câmara dos Senhores Deputados da Naçáo Portugueza, n. 14, 17 de dezembro de 1858, p. 331.
} 
Na Vaga do trabalho escravo: o tráfico de trabalhadores engajados de MoçambiQue para a IlHa

José, escravo de Domingos Ferreira, de Moçambique: foi vendido pelo seu dono a um "mouro" que o levou para Comoro onde vendeu aos franceses.

António, escravo de Patrício, de Quelimane: raptado por um “mouro” em Angoche; vendido a mercadores swahilis; levado para Comores onde foi vendido a franceses.

Emílio Muquema, escravo de Francisco José Menezes, de Moçambique; raptado pelos Macuas e vendido em Quitangonha ao "mouro" Ali, que o vendera ao capitão francês.

Vitorino e Carlos, escravos de Jacinto Jesus da Silva, de Moçambique, raptados pelos Macuas e vendidos em Quitangonha.

Iria, escrava de Abduldurama, capitão de Quitangonha: o seu dono vendeu-a. ${ }^{40}$

Em julho de 1858, outra embarcação francesa, de nome Alfred, foi detida no porto do Ibo com 105 africanos a bordo. Indagado sobre a proibição de engajar habitantes daquela região, o capitão declarou que, tendo concluído as suas operaçóes nas Ilhas Comores, a barca tinha se dirigido ao Ibo para desembarcar um passageiro e comprar mantimentos. Afirmação em clara contradição com o depoimento dos passageiros que diziam "serem de differentes raças do sertão, menos das Ilhas Comoro", e que foram "arrancados á força de seus domicílios para serem vendidos ao Capitão Cahours da mesma Barca, e passarem a servir nas Possessóes francezas com a denominação de trabalhadores livres”. Os depoimentos iluminam as estratégias do recrutamento à semelhança da obtenção de escravos.

Termo da inquirição aos negros da sobredita Barca, sendo perguntados Jamali Salubi e Sadubiri, responderam: o primeiro que era natural de Chelibaro, homem livre, e que tendo sido marinheiro do Pangaio arabe que conduzia os negros, o Capitão do dito Pangaio o vendera ao Capitão do navio Alfred sem elle ser sabedor, e também um seu sobrinho por nome Salubi, o qual sendo inquirido disse o mesmo, e ambos disseram que estavam a bordo do dito navio contra sua vontade, e em grande constrangimento, e tratados como escravos; sendo também inquirido um negro, por nome Sadubiri, disse que foi vendido por um Arabe ao Capitão, que a sua terra de naturalidade era Mauana, ao pé de Moçambique; mas que tendo sido comprado por um Arabe este o vendera ao Capitão; e disse mais, que reconhecera a um seu irmão por nome Capitão (que é um dos negros libertos da Barca Charles et Georges), que é da tripulação da lancha que levara a tropa para bordo, o que se verificou ser certo. Foram mais inquiridos diversos negros, que todos declararam serem filhos da Mauana, e que foram reduzidos á escravidão, embarcados ha pouco tempo n’um Pangaio que partiu d'um porto próximo a Moçambique para a Ilha de Anjoanes, onde foram vendidos ao Capitão d'esta mesma Barca; que são tratados como escravos, e que se acham todos a bordo contra sua vontade; e que

\footnotetext{
${ }^{40}$ ALMEIDA, Pedro Ramos de. História do colonialismo português em África. Cronologia: v. II - século XIX. Lisboa: Editorial Estampa, 1979, p. 130.
} 
Na Vaga do trabalho ESCravo: o tráfico de trabalhadores engajados de Moçambique para a IlHa REUNIẪO NO PÓS-ABOLIÇÃ̃ DA ESCRAVIDÃO COLONIAL FRANCESA

Paulo Cesar Gonçalves

tendo sido elles reduzidos á escravidão e arrancados de suas terras, era uma illusão suppor que tenham sido engajados ${ }^{41}$.

Outro documento, a correspondência do cônsul britânico em Moçambique com o Foreign Office, datada de 7 de dezembro de 1857, permite avançar um pouco mais a respeito da estratégia francesa:

Navios franceses de 200 a 1000 toneladas estão a ser autorizados a carregar um negro por tonelada com destino à Ilha da Reunião. Formalmente, um representante do Estado francês e as autoridades portuguesas verificam o caráter voluntário do engajamento. A maioria dos navios partiria do Ibo. Circulam boatos que comprometem o desinteresse do governador-geral Vasco Guedes de Carvalho e Menezes no tráfico de émigrés. Os escravos vivem sobretudo na região do Niassa (deslocação que duraria meses) e seriam conservados em paliçadas situadas a uma distância da costa de 2 ou 3 dias de marcha. Na Ilha da Reunião, os trabalhadores não poderiam escolher o seu senhor e receberiam de 6 a 8 xelins mensais, além da alimentação e vestuário. Lá não seria permitido o castigo corporal. Após 5 anos de trabalho a maioria não regressaria, passando à categoria de trabalhadores livres mais bem pagos. ${ }^{42}$

O problema era recorrente. Entre outubro e novembro do mesmo ano, outros dois navios de bandeira francesa, Marie et Carolina e Maris Stella, foram proibidos pelas autoridades coloniais de embarcar no porto da Ilha do Ibo os trabalhadores engajados para Reunião ${ }^{43}$. A vistoria a bordo da Marie et Caroline encontrou indícios de que o objetivo era realizar "um carregamento de negros para a Ilha da Reunião, como é notório que o tinham feito mui recentemente sete navios procedentes da mesma Ilha”. Tais “indícios de escravatura” foram descritos em documento:

$1^{\circ}$, por ter coberta corrida com tábuas volantes; $2 .^{\circ}$, por ter um grande fogão, também volante, com Ires caldeiras para cozinhar; $3 .^{\circ}$, por ter uma grande jarra de agua com cinco chupetas; $4 .^{\circ}$, por ter escotilhas grandes com grades de ferro e cadeado para as fechar; $5 .^{\circ}$, por ter aguada de mais e mantimentos; $6 .^{\circ}$, por ter uma grande latrina no costado do navio; $7 .^{\circ}$, por se achar a bordo quatro pretos pequenos illegalmente; e $8 .^{\circ}$ finalmente, pelos precedentes de ser um

\footnotetext{
${ }^{41}$ Officio do Ministro da Marinha ao dos Negócios Estrangeiros, de 29 de novembro de 1858. Documentos relativos ao apresamento, julgamento e entrega da barca franceza Charles et Georges: e em geral ao engajamento de negros, debaixo da denominação de trabalhadores livres nas possessóes da coroa de Portugal na costa oriental e occidental de Africa para as colonias francezas: apresentados ás cortes na sessáo legislativa de 1858. Lisboa: Imprensa Nacional, 1858, Apêndice, p. 14-15.

${ }^{42}$ ALMEIDA, Pedro Ramos de. História do colonialismo... op. cit., p. 130-131.

${ }^{43}$ Monarquia Constitucional. Câmara dos Senhores Deputados da Nação Portugueza, n. 16, 20 de dezembro de 1858, p. 198.
} 
Na Vaga do trabalho escravo: o tráfico de trabalhadores engajados de MoçambiQue para a IlHa REUNIẪO NO PÓS-ABOLIÇÃ̃ DA ESCRAVIDÃO COLONIAL FRANCESA

Paulo Cesar Gonçalves

navio vindo das Ilhas de Bourbon [Reuniāo], para onde consta terem sido transportados d'esta Província grande numero de negros ${ }^{44}$.

O recrutamento e transporte dos engajados eram operaçóes bastante arriscadas não só devido à fiscalização portuguesa nos portos de embarque e à britânica nos mares, mas também pelas rebelióes a bordo das embarcaçôes - prova cabal da resistência das vítimas desse tipo de tráfico. Exemplos não faltaram, como o do navio Happy que estava fundeado em uma das baias de Madagascar com grande número de engajados que se rebelaram, tentaram matar a tripulação e fugiram para a terra, onde parte foi capturada e levada para Reunião. O tribunal que examinou o caso - conforme as palavras proferidas na Câmara dos Deputados pelo Ministro da Marinha, Sá da Bandeira, - verificou “que os negros eram provenientes quasi todos do continente africano (os mais eram habitantes de Madagascar)" e esclareceu como todos foram encaminhados até os portos para serem negociados:

(...) foram levados em pangaios pelos arabes que os iam comprar e que depois os vendiam aos franceses; fazendo-se a bordo perante um delegado, que n'este caso era um sargento, uma cousa chamada contrato de engajamento de trabalhadores livres; e provou-se tambem que os proprios arabes que vendiam os negros aos francezes, os tinham feito rebellar para os capturar depois e venderem-os uma segunda vez..$^{45}$

Os depoimentos dos engajados e os documentos oficiais trazem luz a um aspecto discutido pela historiografia acerca da particularidade do recrutamento de trabalhadores na África Oriental, revelando continuidade com o tráfico de escravos: a presença de negreiros árabes no litoral norte do território, com raízes no sultanato de Zanzibar, o qual os portugueses nunca conseguiram expulsar ou neutralizar conforme seus interesses coloniais. Esses traficantes, conhecidos como mujojos, aliados as chefes macuas e ajauas ${ }^{46}$, escravizavam contingentes significativos de populaçóes preadas desde o lago Niassa e trazidas até o litoral, na esteira das caravanas de marfim, para serem vendidas aos recrutadores franceses ${ }^{47}$. Denunciam, ainda, práticas alternativas para contornar proibições francesas e portuguesas

\footnotetext{
${ }^{44}$ Officio do Ministro da Marinha ao dos Negócios Estrangeiros, de 30 de março de 1858. Documentos relativos... da barca franceza Charles et Georges. op. cit., p. 53.

${ }^{45}$ Monarquia Constitucional. Câmara dos Senhores Deputados da Nação Portugueza, n. 16, 20 de dezembro de 1858, p. 207.

${ }^{46}$ Mujojo: comerciante arábio que frequentava os portos e o interior de Moçambique traficando escravos. Ajaua: etnia que habitava o sul do Lago Niassa. No século XIX, foram os principais fornecedores de escravos para os árabes de Zanzibar e fizeram deste tráfico sua principal atividade econômica apresando indivíduos nas tribos macua e nianja que eram levados em suas caravanas do interior para o litoral. Macua: maior grupo étnico em Moçambique, cujo território (Macuana), estava compreendido entre e os rios Rovuma, Zambeze e Lugenda e o Índico. Nas guerras tribais, foram as principais vítimas da escravização para o tráfico.

${ }^{47}$ CAPELA, José. O tráfico de escravos... op. cit., p. 233-234.
} 


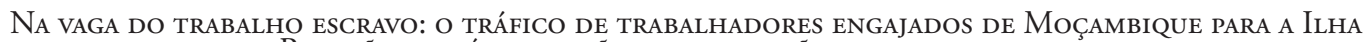
REUNIẪO NO PÓS-ABOLIÇÃ̃ DA ESCRAVIDÃO COLONIAL FRANCESA

Paulo Cesar Gonçalves

ao recrutamento de africanos: o favorecimento do tradicional tráfico clandestino feito por mercadores suaílis ${ }^{48}$ através de pangaios árabes que embarcavam os engajados nos portos da costa de Moçambique para levá-los a Madagascar e Comores, onde seriam vendidos aos franceses ${ }^{49}$.

O recrutamento de colonos livres engajados nos portos de Moçambique, portanto, refletia-se pelo interior das fronteiras coloniais e nas áreas adjacentes, movimentando o comércio de seres humanos, na esteira da escravidáo e do tráfico de escravos por terra, para atender à demanda por força de trabalho nas colônias francesas do Índico. Uma vez comprados e embarcados, os cativos eram libertados e engajados através de contratos de trabalho por tempo determinado. Apesar de serem comprados, no contrato, aparecia apenas a menção "negro livre", indicando que essas operaçóes de engajamento, sem referência a qualquer alforria preexistente, representavam hábil manobra para deixar implícito a "condição livre" e que os "recrutados" firmaram o acordo com total liberdade. Ao atestarem o "estatuto livre" dos "contratados" e estabelecerem o pagamento de salários, os contratos permitiam proteção jurídica contra a acusação de tráfico de escravos ${ }^{50}$.

Mesmo após o incidente com a barca Charles et Georges e de outros casos acima citados, os quase 24 mil engajados apontados por Flory, entre 1856 a 1861, indicam que os navios franceses não pararam de chegar a Moçambique. Northrup, para um período mais extenso, entre 1841 e 1860, apresenta dados agrupados por decênios, o que possibilita averiguar o volume desse tipo de engajamento, sobretudo na década de 1850: apenas 574, de 1841-1850, e 33.645, de 1851-1860, totalizando pouco mais de 34 mil africanos, ou seja, quase metade do fluxo de indianos (69 mil), a principal força de trabalho engajado para Reunião $0^{51}$.

As tentativas de engajamento por parte dos proprietários das plantations de Reunião não cessaram nas duas décadas seguintes, sob certa complacência dos governos coloniais, mas com resistência por parte da metrópole portuguesa. Em 1877, o cônsul britânico em Reunião noticiou que os plantadores daquela ilha estavam novamente interessados no recrutamento de mão de obra em Moçambique e bastante empenhados na negociação com as autoridades portuguesas. Mas o que chama atenção são duas portarias que permitiram a contrataçáo de trabalhadores para a colônia britânica de Natal (2 de agosto de 1875) e para

\footnotetext{
${ }^{48}$ Suaílis: povos islamizados da costa do Índico e ilhas adjacentes; eram os principais fornecedores de escravos na costa Norte de Moçambique.

${ }^{49}$ CAPELA, José; MEDEIROS, Eduardo. O tráfico de escravos... op. cit., p. 51; CAPELA, José. O tráfico de escravos nos portos de Moçambique. op. cit., p. 57.

${ }^{50}$ FLORY, Céline. Alforriar sem libertar. op. cit., p. 99-100. O relatório do governador de Angola de 1861 traz cópia do modelo de contrato entre engajadores franceses e trabalhadores africanos, composto por oito artigos que os obrigava a dez anos de serviço, 26 dias por mês, em qualquer tipo de trabalho, com direito a salário (descontadas as dívidas referentes ao transporte e ao custo da libertação), alojamento, alimentação, tratamento médico e regresso ao local de origem desde que por conta própria. Relatorio do Governador Geral da Provincia de Angola Sebastiāo Lopes de Calheiros e Menezes expedido ao ano de 186. Immigração africana. Lisboa: Imprensa Nacional, 1867, p. 440-442.

${ }^{51}$ NORTHRUP, David. Indentured labor... op. cit., p. 159.
} 


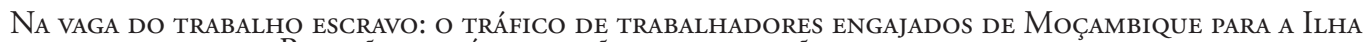

as colônias francesas de Mayotte e Nossi-bé (23 de julho de 1881) mediante um imposto de autorização de saída per capita. Essa última provocou protestos por parte do Foreign Office, sob alegação de ser uma forma disfarçada de tráfico. A pronta resposta do Ministério dos Negócios Estrangeiros português fez observar que a portaria contestada era idêntica àquela que permitia a emigração de trabalhadores africanos para Natal, mas que se fosse comprovado tráfico de escravos, proibiria qualquer saída ${ }^{52}$.

Um testemunho significativo da continuidade do engajamento de africanos veio à luz em 24 de novembro de 1887, com a Portaria do Ministério dos Negócios da Marinha e do Ultramar, permitindo a emigração voluntária de trabalhadores de Moçambique para Reunião, o que acabou originando, em 13 de julho de 1888, o "Regulamento do serviço da emigração voluntaria dos portos de Moçambique e Inhambane para a colonia franceza da Ilha da Reunião”. Os tempos eram diferentes, pois a escravidão já fora abolida no Império português, mas a demanda por mão de obra na colônia francesa permanecia intensa.

Diversos fatores concorreram para a elaboração do regulamento: a insuficiência das portarias anteriores para resolver o problema da proibição dessa emigração; a necessidade de regular a emigração evitando as saídas clandestinas; o imperativo de reunir em um só corpo de doutrina as disposiçôes sobre o tema, facilitando sua execução e divulgação; o dever do país de tutelar a saída de seus súditos, protegendo-os de interesses obscuros. Outro ponto chama atenção: a deliberação do governo-geral de permitir a emigração voluntária ratificaria o direito de as pessoas disporem sobre si mesmas, dever de uma nação independente e livre, sob os princípios liberais. Afinal, afirmava a portaria, "a emigração era o meio pelo qual a civilização dos povos mais cultos desbravou terras inóspitas, desentranhou riquezas que o solo ocultava, desenvolveu as indústrias e estabeleceu relaçôes comerciais onde antes não existiam" 53 .

O regulamento apresentava três capítulos. I. "Dos contratos provisorios e registos"; II. "Da policia maritima”; III. "Disposiçóes penaes". Trazia em anexo, os modelos dos documentos necessários: (A) contrato provisório de prestação de serviços que deveria ser assinado pelos dois outorgantes, duas testemunhas, o intérprete do Estado e pelo agente consular; (B) formulário para identificação dos emigrantes voluntários a ser visado pelo agente consular francês e pelo agente de emigração; (C) formulário com as informaçóes do navio - bandeira, tripulação e passageiros embarcados - com espaço para a assinatura do capitão ${ }^{54}$.

Ao estabelecer as regras para os contratos, o Capítulo I fornecia informações importantes sobre a dinâmica do recrutamento, transporte e destino de emigrantes. A primeira medida estabelecia a criação de um depósito temporário em Moçambique e outro em Inhambane para os indígenas que quisessem contratar seus serviços para Reunião - a supervisão ficaria a cargo das autoridades portuguesas, mas as despesas, sob responsabilidade do governo

\footnotetext{
${ }^{52}$ ALMEIDA, Pedro Ramos de. História do colonialismo... op. cit., p. 179, 221 e 226-227.

${ }^{53}$ Regulamento do serviço da emigração voluntaria dos portos de Moçambique e Inhambane para a colonia franceza da Ilha da Reunião. Moçambique: Imprensa Nacional, 1888, p. 78.

${ }^{54}$ Regulamento... op. cit., p. 85-87.
} 
Na Vaga do trabalho escravo: o tráfico de trabalhadores engajados de MoçambiQue para a IlHa

francês. Os contratos só poderiam ser firmados com proprietários ou diretores de grandes exploraçôes agrícolas e deveriam obedecer aos preceitos do regulamento do governo francês de 27 de agosto de 1887 para imigração e trabalho naquela colônia. O controle de saída seria efetuado pela emissão de passaporte, a um custo de $2 \$ 500$ réis. Antes de embarcar, os emigrantes deveriam ser apresentados pelo responsável francês na secretaria do governo-geral ou distrito a fim de se fazer o registro, verificar o passaporte, confirmarem se conheciam as condiçóes dos seus contratos e se partiam por sua livre vontade ${ }^{55}$.

O contrato provisório de locação de serviços era bastante minucioso e deveria conter os seguintes dados: a espécie e natureza do trabalho, tempo de duração do contrato, valor do salário, ração diária, vestuário, horas de serviço diário, a consignação expressa do direito de repatriação logo ao fim do contrato em caso de não renovação. $\mathrm{O}$ emigrante só poderia embarcar apresentando seu passaporte e o contrato de trabalho. Os contratos definitivos seriam firmados na Ilha Reuniáo, logo após o desembarque dos emigrantes, nos termos da legislação francesa, sendo obrigatório o envio de uma cópia ao governo-geral ${ }^{56}$.

A fiscalização das embarcaçôes para o transporte dos emigrantes, tema do Capítulo II, ficava a cargo do capitão dos portos. Definiram-se os navios sujeitos à visita de polícia: vapores com ou sem privilégio de paquete em carreiras certas ou incertas, com escala em um ou mais portos da província de Moçambique, e as embarcaçóes a vela que navegavam para os portos das colônias estrangeiras. Estabelecia que qualquer navio de viagem de longo curso que conduzisse para algum porto estrangeiro mais de 24 passageiros portugueses seria considerado como empregado no transporte de colonos e emigrantes, ficando sujeito às penas da lei de repressão à emigração clandestina, ou mesmo impedido de sair até satisfazer as obrigaçōes legais ${ }^{57}$.

Eram consideradas também as condiçôes das embarcaçóes que transportavam os emigrantes: alojamento, qualidade da alimentação, medicamentos suficientes e a quantidade de passageiros por tonelagem. Após a fiscalização, o capitáo deveria entregar a lista de todos os passageiros juntamente com os passaportes e o contrato de locação de serviços para conferência. Concluída a visita, ninguém mais poderia ser admitido no navio. O Capítulo III definia as penalidades. Patrocinar a clandestinidade - emigrantes sem passaporte ou contrato de trabalho -, transportar passageiros em número acima do permitido, ser responsável por maus tratos e por condiçôes precárias de higiene e alimentação, resultariam em multas pesadas e até prisão. Os depoimentos dos passageiros seriam tomados pelo cônsul de Portugal na Reuniáo e enviados ao governo-geral ${ }^{58}$.

Em 1891, o deputado Augusto de Castilho, governador-geral de Moçambique entre 1885-1889, e autor do projeto que regulamentou a emigração para Reunião, alertava, em

\footnotetext{
${ }^{55}$ Regulamento... op. cit., p. 79.

${ }^{56}$ Ibidem, p. 80.

${ }^{57}$ Ibidem, p. 81-82.

${ }^{58}$ Ibidem, p. 82-85. 


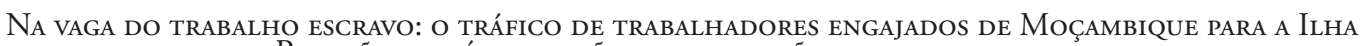

discurso na Câmara dos Deputados, para a continuidade do tráfico de trabalhadores forçados, em especial, dos embarques clandestinos e da suposta complacência das autoridades responsáveis pela fiscalização:

Sr. presidente, desejo tambem dizer á camara que ultimamente têem occorrido no districto de Inhambane alguns acontecimentos de uma certa gravidade. Ha alguns annos que ali é permitida pelo governo a emigração de pretos para as colonias inglezas do Natal e do Cabo, e posteriormente foi também permitido para a colonia franceza da Reuniáo.

Esta emigraçáo, sobretudo a que se faz para a ilha da Reuniāo, a qual a principio inspirou ao governo inglez receios de que fosse conduzida menos liberalmente e de que assumisse um certo caracter parecido com o antigo trafico de escravos, foi regulamentada com toda a severidade e cuidado.

O regulamento, que eu proprio elaborei, e que mereceu a approvação do governo de sua Magestade, compendiando tudo quanto havia disperso pela legislaçáo com respeito á emigração, encerra, creio eu, todas as providencias necessarias para se fazer a emigração com toda a liberdade, evitando-se todavia que essa emigração se transforme em qualquer cousa com um nome mais feio e que envergonhe a nação.

(...)

Não quero crer que o governador geral da provincia, caracter probo e meu amigo ha longos annos, tenha conhecimento d'estes factos, nem quero crer que o governo aqui o tenha; mas, como recebi estas noticias de pessoa para mim de toda a confiança, tenho desejo de que o governo se informe cuidadosamente do que ha, e proceda com a maior severidade para se evitar o escandalo de se estar em um porto nosso a fazer emigração por um modo que se parece muito com o trafico de escravos. ${ }^{59}$

Em sua fala, Castilho não discorreu sobre as condiçôes de trabalho em Reuniáo nem forneceu números do recrutamento. Informaçóes importantes que permitem compreender a repulsa dos trabalhadores em se dirigirem à colônia francesa. Segundo Capela, do porto de Inhambane, entre 1888 e 1890, foram transportados cerca de dois mil engajados, sendo que, no último ano, apenas 18 - um indício de que ninguém mais queria ir para a ilha devido à escassez da remuneraçáo e ao temor de náo conseguir retornar ao final do contrato ${ }^{60}$. De fato, o que deu cabo a essa forma de recrutamento foi uma revolta, em 1891, dos engajados moçambicanos porque lhes recusaram o repatriamento prometido depois de três anos de servidão ${ }^{61}$. Trabalho forçado, perda do direito de ir e vir, baixíssima remuneração, em suma, no crepúsculo do Oitocentos, nem mesmo o minucioso regulamento português de 1887 conseguiu romper as amarras da escravidão e do tráfico negreiro.

\footnotetext{
${ }^{59}$ Monarquia Constitucional. Câmara dos Senhores Deputados da Nação Portugueza, n. 27, $1^{\circ}$ de julho de 1891, p. 8.

${ }^{60}$ CAPELA, José. O escravismo colonial em Moçambique. Porto: Afrontamento, 1993, p. 113.

${ }^{61}$ ALPERS, Edward A. "le caractère d'une traite"... op. cit., p. 23.
} 
Na Vaga do trabalho escravo: o tráfico de trabalhadores engajados de MoçambiQue para a IlHa

$\mathrm{Na}$ colônia portuguesa, no entanto, outro problema ganhava contornos definitivos no quartel final do século XIX. A emigração para a Ilha Reunião e o grande fluxo que se dirigia às minas do Transvaal, Rodésia e África do Sul, associados à falta de mão de obra para agricultura, começavam a colocar em xeque os recentes acordos para exportação de africanos. Vale recorrer, mais uma vez, às palavras do deputado Castilho:

Além d'isto, a agricultura no districto de Inhambane está soffrendo com a falta de braços, e mais soffrerá para o futuro se consentirmos que continuem a ser exportados em massa muitos milhares de pretos, que no seu proprio paiz encontrariam facilmente a occupação e que assim estão empobrecendo os cofres do districto para encherem alguns de particulares. ${ }^{62}$

Se o êxodo de trabalhadores contratados representava fonte de divisas através dos emolumentos pagos pelos passaportes e licenças, na ótica metropolitana, uma preocupação que ultrapassava as questóes morais ligadas ao tráfico e ao trabalho escravo alcançava, então, dimensão econômica essencial no sentido da exploração colonial e do desenvolvimento de Moçambique.

Colonizar e desenvolver o ultramar, já há alguns anos após a abolição do trabalho escravo em 1878, implicaria abundância de mão de obra não apenas em termos quantitativos, mas essencialmente qualitativos - no sentido da sua disponibilidade e da condenaçáo moral da "indolência" diante da missão civilizadora portuguesa em África. Se o engajamento era a forma encontrada pelos impérios estrangeiros para conseguir trabalhadores, restava a Portugal tentar regular e tutelar a emigração, além de legislar obrigando os nativos ao trabalho. Nesse sentido, a regulamentação da emigração das populaçôes indígenas complementou o lento processo de abolição da escravidão e a legislação sobre o trabalho forçado. Como observaram Capela e Medeiros, quando o tráfico chegou ao fim, o comércio de trabalhadores continuou sob a forma de engajados no lugar dos escravos e, após a abolição da escravidão, através do recrutamento de grandes contingentes de mão de obra forçada para o capital colonial. Coerçáo e violência, os mesmos mecanismos de obtenção de escravos na época do tráfico, portanto, conferiram a continuidade das estratégias para obrigar populaçôes nativas ao trabalho sistemático e produtivo ${ }^{63}$.

O decreto de 14 de dezembro de 1854 estabeleceu que todo escravo importado por terra, em domínios portugueses, passaria à condição de "liberto", mas com a obrigação de servir seu senhor por dez anos, podendo, inclusive, ter o tempo de serviço vendido a outro. Em 29 de abril de 1858, decretou-se que a abolição da escravidáo em todo o império ocorreria no prazo de 20 anos. O decreto de 25 de fevereiro de 1869 antecipou a abolição, transformando todos os escravos em libertos, que permaneceriam nessa condição até 29 de abril de 1878 .

\footnotetext{
${ }^{62}$ Monarquia Constitucional. Câmara dos Senhores Deputados da Naçâo Portugueza, n. 27, 10 de julho de 1891, p. 8. Sobre a cumplicidade dos governadores com o recrutamento e o tráfico de escravos e engajados ver CAPELA, José; MEDEIROS, Eduardo. O tráfico de escravos... op. cit.

${ }^{63}$ CAPELA, José; MEDEIROS, Eduardo. O tráfico de escravos... op. cit., p. 109.
} 


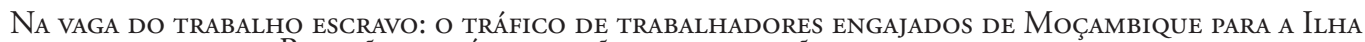

$\mathrm{Na}$ década de 1870 , foi promulgada legislação essencial para a extinção da condição servil e regulação do trabalho no ultramar português. A lei de 29 de abril de 1875 declarou a liberdade dos libertos, que ficavam sujeitos à tutela pública e obrigados a contratar os seus serviços por dois anos, de preferência, com o antigo senhor. O regulamento de 20 de dezembro de 1875 estabeleceu o trabalho obrigatório para os considerados libertos pelos decretos de 1854 e 1869, os filhos de mulher escrava, libertados pela lei de 1856, e todos aqueles introduzidos originalmente como libertos.

Seixas, em uma perspectiva legalista, considera que a lei e o regulamento de 1875 constituíram medidas fundamentais na transição para o trabalho livre, pois, embora a extinção da condição servil ficasse condicionada pela obrigação de contratar, foi o passo essencial para a atribuição de liberdade jurídica (formal) aos libertos ou filhos de escravas. O processo foi coroado em 21 de novembro de 1878, com o regulamento que pôs fim à obrigaçáo de contratar estipulada em $1875^{64}$. Na verdade, apesar de mais liberal e de despertar forte oposição, esse aparato legal não impediu a persistência do trabalho forçado - a comprovação de seus limites em termos das práticas sociais e econômicas.

Duas décadas depois, a suposta inferioridade e a caracterização do africano como indolente serviram de justificativa para um novo dispositivo legislativo, publicado em $26 \mathrm{de}$ novembro de 1899, o "Regulamento do Trabalho Indígena", que condenava a "vadiagem" e estabelecia a obrigatoriedade do trabalho e os meios legítimos para assegurar o cumprimento dessa obrigação - trabalho correcional e, até mesmo, a puniçấo física. Disposiçôes que, segundo Jerónimo, legitimaram a emergência de um sistema de comércio de mão de obra indígena, coagindo o nativo a trabalhar nos termos definidos pelos interesses econômicos associados à administração colonial portuguesa ${ }^{65}$.

As palavras de Antonio Enes ${ }^{66}$ exemplificam essa forte corrente do ideário metropolitano à época: "os interesses econômicos recomendavam ao legislador que diligenciasse aproveitar e conservar os hábitos de trabalho que a escravatura impunha aos negros" ${ }^{\text {"67 }}$. A escravidão, condenada moralmente, paradoxalmente, apresentava-se como positiva quanto à sua contribuição para induzir o hábito - moral e econômico - do trabalho entre a população indígena, naturalizando, assim, a imposição do trabalho forçado.

Quanto à emigração, já na década de 1870, a demanda externa por mão de obra de Moçambique não passou incólume aos funcionários da colônia. Eles perceberam rapidamente que a saída de indígenas era uma exportação de mercadoria e poderia ser objeto

\footnotetext{
${ }^{64}$ SEIXAS, Margarida. O trabalho escravo e o trabalho forçado na colonização portuguesa oitocentista: uma análise histórico-jurídica. Revista Portuguesa de História. Coimbra, t. 46, 2015, p. 229.

${ }^{65}$ JERÓNIMO, Miguel B. Livros brancos, almas negras. A "missão civilizadora" do colonialismo português, c.1870-1930. Lisboa: ICS, 2009, p. 90.

${ }^{66}$ António Enes, importante figura da administração colonial portuguesa, foi Ministro da Marinha e Ultramar entre 14 de outubro de 1890 e 25 de maio de 1891 e teve importante papel nas intervençóes militares nas colônias africanas. Em 1894, foi nomeado Comissário Régio em Moçambique.

${ }^{67}$ Antonio Enes. Moçambique, 1913. Apud JERÓNIMO, Miguel B. Livros brancos... op. cit., p. 91.
} 


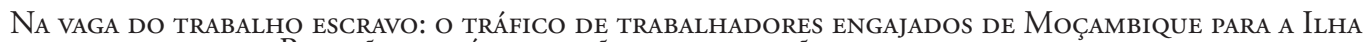

de impostos, desde que regulamentada e controlada. Em 1875, Lourenço Marques e Moçambique foram designados como portos de saída de migrantes com passaporte e, em 1885, Inhambane. Com a construção da via férrea a partir de Lourenço Marques até a região das minas, estabeleceram-se as regras para os acordos sobre mão de obra entre Moçambique e África do Sul ${ }^{68}$. Em 1897, Mouzinho de Albuquerque ${ }^{69}$ instituiu o "Regulamento para o engajamento de indígenas para a República Sul-Africana”, impondo a cada recrutador uma série de cobranças inerentes à burocracia da autorização de saída. Após a Guerra dos Bôeres, foi assinado o Modus Vivendi, de 18 de dezembro de 1901, restabelecendo o recrutamento ${ }^{70}$.

De exportador de escravos de suas possessóes africanas, Portugal passou a intermediar o comércio de "mão de obra livre" de mesma origem. Mas, ao mesmo tempo, perante as disputas imperialistas na África e em nome do desenvolvimento econômico e civilizatório das províncias ultramarinas, haveria de se ocupar da utilização do trabalho nativo apoiado na coerção jurídica, diversamente do processo de coerção econômica característico dos contratos de engajamento de trabalhadores para a Ilha Reuniáo. Guardadas as particularidades, trabalho escravo e trabalho forçado constituíram-se em instrumentos da colonização moderna portuguesa, assim como da francesa, onde as amarras da escravidáo perdurariam sob a égide dos contratos de engajamento de "colonos livres" ou através dos regulamentos de trabalho forçado.

O engajamento de "colonos livres" e a imigração sob contrato - em suma, o trabalho forçado - foram soluçóes encontradas para complementar e substituir a mão de obra escrava nas plantaçôes das áreas tropicais do globo, em resposta às expectativas locais da abolição do tráfico e da escravidão, mas também ao crescimento da demanda por produtos específicos, que expandiu as terras cultivadas e os investimentos ultramarinos.

Objeto de análise deste artigo, o engajamento de trabalhadores da África Oriental portuguesa para Reunião permite identificar alguns aspectos associados ao capitalismo em termos de redução de custos da força de trabalho. Após o fim da escravidão no Império francês - e até antes -, a prática do engajamento de trabalhadores indicou os limites da modernidade e

${ }^{68}$ ALEXANDRE, Valentim; DIAS, Jill (orgs.). O Império africano (1825-1890). op. cit., p. 614-615.

${ }^{69} \mathrm{Em}$ 1888, Joaquim Augusto Mouzinho de Albuquerque foi nomeado secretário-geral do governo do Estado da Índia e, em 1890, governador do distrito de Lourenço Marques, cargo que ocupou até 1892. Em 1894, regressou à colônia para debelar rebeliôes indígenas no sul de Moçambique. Destacou-se nas campanhas de África, nomeadamente a que levaria à prisão do chefe vátua Gungunhana, em 1895. Foi governador-geral de Moçambique e Comissário Régio entre 1896 e 1897, quando pediu demissão.

${ }^{70}$ BOUENE, Felizardo; SANTOS, Maciel. O modus vivendi entre Moçambique e o Transvaal (1901-1909). Um caso de "imperialismo ferroviário". Africana Studia. Porto, n. 9, 2006, p. 243 e 246. 
Na Vaga do trabalho escravo: o tráfico de trabalhadores engajados de MoçambiQue para a IlHa

do progresso que ainda desafiavam a dignidade humana em nome das exigências da divisão internacional do trabalho que, na vaga do trabalho escravo, amparou-se no emprego de mão de obra forçada nas áreas de plantations.

As estratégias de recrutamento descritas acima não deixam dúvida sobre a continuidade do tráfico de escravos e da escravidão, mas mostram também o imperativo do trabalho forçado, expressão máxima do baixo custo, como demanda do capitalismo em termos da reprodução de preços competitivos no mercado mundial cada vez mais estratificado espacial e hierarquicamente. A prática do "resgate" de escravos até poderia levar à liberdade, mas o objetivo principal era obrigar os indivíduos "resgatados" a trabalharem por muitos anos a serviço do "contratador", produzindo trabalhadores dependentes, uma servidáo com duração determinada que alienava direitos intrínsecos à concepção de liberdade. Efeito similar ocorreu no ultramar português com a emancipaçáo dos escravos acompanhada pela legislação do trabalho forçado.

As várias formas de coerção, portanto, constituíram historicamente a base das estratégias de obtenção de trabalhadores para rebaixar os custos da produção e ampliar a oferta de mão de obra. O fato de o trabalho forçado conviver no mesmo tempo e espaço com formas de escravidão e trabalho livre no passado, inclusive sob o manto do progresso capitalista, aponta, em essência, para a necessidade de se repensar a equivocada oposição dualista contemporânea entre trabalho escravo e trabalho livre e entre capitalismo e escravidáo. Na verdade, talvez nem seja necessária uma regressão histórica. Basta a constatação das inúmeras relaçôes precárias de trabalho atuais, muitas delas análogas à escravidão, para comprovar a falsidade dessa dicotomia.

\section{Fontes documentais}

LEGISLAÇÃO RÉGIA. Repartição da Marinha, Portaria no 1.394 de 27 de fevereiro de 1855.

LEGISLAÇÃO RÉGIA. Repartição da Marinha, Portaria de 30 de julho de 1856.

LEGISLAÇÃO RÉGIA. Ministério dos Negócios da Marinha e Ultramar. Seção do Ultramar, Portaria de 20 de novembro de 1857.

MONARQUIA CONSTITUCIONAL. Câmara dos Senhores Deputados da Nação Portugueza, n. 14, 17 de dezembro de 1858.

MONARQUIA CONSTITUCIONAL. Câmara dos Senhores Deputados da Nação Portugueza, n. 16, 20 de dezembro de 1858.

MONARQUIA CONSTITUCIONAL. Câmara dos Senhores Deputados da Nação Portugueza, n. 27, 1º de julho de 1891.

Documentos relativos ao apresamento, julgamento e entrega da barca franceza Charles et 
Na Vaga do trabalho escravo: o tráfico de trabalhadores engajados de MoçambiQue para a IlHa

Georges: e em geral ao engajamento de negros, debaixo da denominação de trabalhadores livres nas possessóes da coroa de Portugal na costa oriental e occidental de Africa para as colonias francezas: apresentados ás cortes na sessão legislativa de 1858. Lisboa: Imprensa Nacional, 1858, Apêndice.

Regulamento do serviço da emigração voluntaria dos portos de Moçambique e Inhambane para a colonia franceza da Ilha da Reunião. Moçambique: Imprensa Nacional, 1888.

\section{Referências}

ALEXANDRE, Valentim. Origens do colonialismo português moderno. Lisboa: Sá da Costa, 1979.

ALEXANDRE, Valentim; DIAS, Jill (orgs.). O Império africano (1825-1890), v. X. SERRÃO, Joel; MARQUES, A. H. de Oliveira (dir.). Nova História da expansão portuguesa. Lisboa: Editorial Estampa, 1998.

ALLEN, Richard B. The Mascarene slave-trade and labour migration in the Indian Ocean during the Eighteenth and Nineteenth Centuries. In: CAMPBELL, Gwyn (org.). The structure of slavery in Indian Ocean, Africa and Asia. London: Frank Cass, 2004, p. 33-50.

ALLEN, Richard B. European slave trading in the Indian Ocean, 1500-1850. Athens: Ohio University Press, 2014.

ALLEN, Richard B. Slaves, convicts, abolitionism and the global origins of the postemancipation indentured labor system. Slavery \& Abolition, v. 35, n. 2, p. 328-348, 2014. ALMEIDA, Pedro Ramos de. História do colonialismo português em África. Cronologia: v. II - século XIX. Lisboa: Editorial Estampa, 1979.

ALPERS, Edward A. "le caractère d'une traite d'esclaves déguisée (the nature of a disguised slave trade)"? Labor recruitment for La Réunion at Portuguese Mozambique, 1887-1889. Ufahamu: A Journal of African Studies, v. 40, n. 1, p. 3-32, 2018.

BLACKBURN, Robin. A queda do escravismo colonial: 1776-1848. Rio de Janeiro: Record, 2002.

BOUENE, Felizardo; SANTOS, Maciel. O modus vivendi entre Moçambique e o Transvaal (1901-1909). Um caso de "imperialismo ferroviário". Africana Studia. Porto, n. 9, p. 239268, 2006.

CAPELA, José. O escravismo colonial em Moçambique. Porto: Afrontamento, 1993.

CAPELA, José. O tráfico de escravos nos portos de Moçambique. Porto: Afrontamento, 2002.

CAPELA, José; MEDEIROS, Eduardo. O tráfico de escravos de Moçambique para as ilhas do 
Na Vaga do trabalho escravo: o tráfico de trabalhadores engajados de MoçambiQue para a IlHa

Índico, 1720-1902. Maputo: Universidade Eduardo Mondlane, 1987.

CHAILLOU-ATROUS, Virginie. La reprise de l'immigration africaine à La Réunion à la fin du XIXème siècle: de la traite déguisée à l'engagement de travail libre. French Colonial History, v. 16, p. 27-54, 2016.

FLORY, Céline. Alforriar sem libertar: a prática do "resgate" de cativos africanos no espaço colonial francês no século XIX. Revista Mundos do Trabalho. Campinas/SP, v. 3, n. 6, p. 93104, 2011.

FLORY, Céline. De l'esclavage à la liberté forcée. Histoire des travailleurs africains engagés dans la Carä̈be française du XIXe siècle. Paris: Société des Africanistes, 2015.

FUMA, Sudel. Histoire d'un people: la Réunion (1848-1900). Saint-Denis: Université de la Réunion/Editions CNH, 1994.

GRADEN, Dale. O envolvimento dos Estados Unidos no comércio transatlântico de escravos para o Brasil (1840-1858). Afro-Ásia. Salvador, v. 35, p. 9-35, 2007.

JERÓNIMO, Miguel Bandeira. Livros brancos, almas negras. A "missão civilizadora" do colonialismo português, c.1870-1930. Lisboa: ICS, 2009.

MAMIGONIAN, Beatriz G. Em nome da liberdade: abolição do tráfico de escravos, o direito e o ramo brasileiro do recrutamento de africanos (Brasil - Caribe britânico, 18301850). Revista Mundos do Trabalho. Campinas/SP, v. 3, n. 6, p. 67-92, 2011.

NORTHRUP, David. Indentured labor in the age of imperialism, 1834-1922. Nova York: Cambridge University Press, 1995.

SAES, Laurent Azevedo Marques. A primeira abolição francesa da escravidão (4 de fevereiro de 1794) e o problema dos regimes de trabalho. Saeculum - Revista de História. João Pessoa, v. 29, p. 125-143. 2013.

SEIXAS, Margarida. O trabalho escravo e o trabalho forçado na colonização portuguesa oitocentista: uma análise histórico-jurídica. Revista Portuguesa de História. Coimbra, t. 46, p. 217-236, 2015.

STANZIANI, Alessandro. Travail, droits et immigration. Une comparaison entre l'île Maurice et l'île de La Réunion, années 1840-1880. Le Mouvement Social, v. 4, n. 241, p. 47-64, 2012.

STANZIANI, Alessandro. Beyond colonialism: servants, wage earners and indentured migrants in rural France and on Reunion Island (c. 1750-1900). Labor History. Londres, v. 54, n. 1, p. 64-87, 2013.

STANZIANI, Alessandro. Bondage: labor and rights in Eurasia from the Sixteenth to the early Twentieth centuries. Nova York; Londres: Berghahn Books, 2014.

TEELOCK, Vijaya; VERNET, Thomas (orgs.). Traites, esclavage et transition vers l'engagisme: perspectives nouvelles sur les Mascareignes et le sud-ouest de l'océan Indien. Réduit: 
Na VAga do trabalho escravo: o tráfico de trabalHadores engajados de Moçambique para a IlHa REUNIÂO NO PÓS-ABOLIÇÃO DA ESCRAVIDÃO COLONIAL FRANCESA

Paulo Cesar Gonçalves

Université de Maurice, 2015.

TOMICH, Dale. Pelo prisma da escravidão: trabalho, capital e economia mundial. São Paulo: Edusp, 2012. 